\title{
The Importance of Computerized Analysis on Spoilage of Maize (Zea Mays L), Before Harvest and Storage in Osun State, Nigeria
}

\author{
Prince Awojoodu Soji \\ Department of Computer Science and Mathematics, Oduduwa University, Ile-Ife Kingdom, Nigeria
}

\section{Email address:}

awojoodusoji@yahoo.com

\section{To cite this article:}

Prince Awojoodu Soji. The Importance of Computerized Analysis on Spoilage of Maize (Zea Mays L), Before Harvest and Storage in Osun State, Nigeria. European Journal of Biophysics. Vol. 7, No. 2, 2019, pp. 52-60. doi: 10.11648/j.ijebo.20190702.14

Received: May 30, 2019; Accepted: October 9, 2019; Published: November 13, 2019

\begin{abstract}
This research work was carried out, to find the importance of computerized analysis on spoilage of maize (Zea mays L), before harvest and storage in Osun State, Nigeria. 4 Local governments, namely: (Ife East, Ife South, Ife Central and Ife North), local government areas were sampled. 4,000 open questionnaires were distributed to the 4 Local Governments, out of which 1000 was used for farmers, in each local government. A total of 40 different locations were visited in all the four Local Governments, out of which 100 questionnaires were used for farmers in each location. It was gathered that above $70 \%$ of the farmers from the four local governments, supported the importance of computerized analysis on spoilage of maize (Zea mays L), before harvest and storage in Osun State, Nigeria, while below 30\% of the people could not even understand whether there was any needy, on the importance of computerized analysis on spoilage of maize (Zea mays L), before harvest and storage in Osun State, Nigeria or not. The results from the questionnaires when using Pearson two-tailed correlation coefficient revealed that there was a significant difference from the summary data collected from the farmers within the four local government areas visited and sampled, $(\mathrm{p}>0.05)$ table 5. This shows a strong positive correlation, which implying that, the importance of computerized analysis on spoilage of maize before harvest and storage in Osun State, Nigeria. is strongly influenced and enhanced the farmers and people's support, and, had therefore, made this research work to become a reality, $(p>0.05)$, table 5 . The reasons may be due to the fact that, maize (Zea mays L), is not only rich in dietary D and calories which are a good source of energy to our body, it is however served as the most productive grain crops in the middle and northern belts of Nigeria where sunshine is adaptable and rainfall is moderate. And as a basic raw materials to thousands of industrial products that may includes: alcoholic, beverages, pharmaceutical, food sweeteners, food cereals, cosmetic and films, gums, package, textile, paper industries and so on., it is one of African's dominant food crop, that can be consumed in varied forms, such as: maize flour for confectionaries, semo (for swallow with soup), as corn beef, mill (for animals feeding), as roaster corn, it can be boiled or prepared as porridge. Pie chart was used to depict the summary data of each of the local government areas sampled in Ile - Ife Kingdom, of Osun State Nigeria.
\end{abstract}

Keywords: Maize (Zea Mays L), Corn, Harvest, Storage, 4 Local Governments, Osun State, Pearson Correlation

\section{Introduction}

Maize (Zea mays L), is the most productive grain crops in the middle and northern belts of Nigeria where sunshine is adaptable and rainfall is moderate. It is one of the oldest human cultivated crops, [1]. It had a tremendous variability in kernel colour, textile, composition and appearance. It is commonly known as corn in the United States and Canada, is the most important cereal grain Worldwide after wheat and rice. It is also referred to as the cereal of the future, for its nutritional value and utilization of its products, [2].

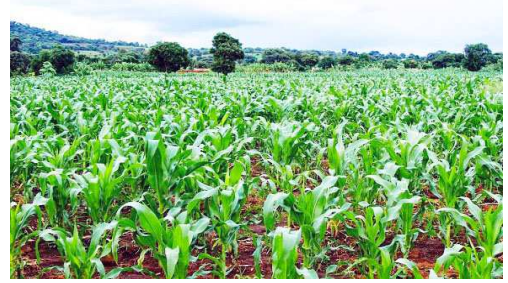

Figure 1. Maize (Zea mays L), as the Cereal of the Future. 
It serves as a basic raw materials to thousands of industrial products that may includes: alcoholic, beverages, pharmaceutical, food sweeteners, food cereals, cosmetic and films, gums, package, textile, paper industries and so on. As one of African's dominant food crops, maize can be consumed in varied forms, such as: maize flour for confectionaries, semo (for swallow with soup), as corn beef, mill (for animals feeding), as roaster corn, it can be boiled or prepared as porridge. It is the most versatile emerging cash crops, having wider adaptability under varied climatic conditions and called the queen of cereals globally. In all parts of Africa, green (fresh) maize is boiled or roasted in its cob and served as snacks. Maize is often consumed as vegetable. In Nigeria, more than $60 \%$ of maize production is also consumed by industrial sector for the production of beer, malt drinks, maize flakes, starch, syrup, dextrose, and animal feed, because there is so much value in the industrial processing of maize, especially into animal feed. The crop is richer in vitamins $\mathrm{A}$, and $\mathrm{E}$, carbohydrates, essential minerals, and contain $9 \%$ protein. They are also rich in dietary D and calories which are a good source of energy, [3]. Maize or grain grows well in rich loamy or sandy loamy soil. Such soil has to be well drained area and suitable on a fairly flat landscape. It grows relatively well in a wider range of soil type than rice. Almost every part of Nigeria can grow maize in their soil. Since sunlight is very necessary and prosper to maize, Nigeria is a country blessed with abundant sunlight, therefore, maize can grow successfully in almost every state of the country.

\subsection{Origin of Maize (Zea Mays L)}

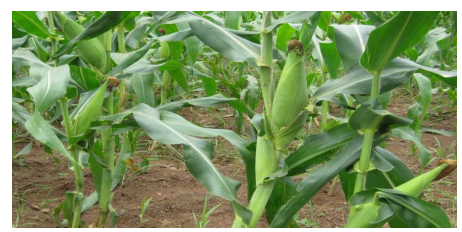

Figure 2. Maize (Zea mays L), Origin in Nigeria.

The centre of its origin was believed to be traced to Mesoamerica region, as far back as 7000 years past, when it was grown as a wild grass called teosinte in the Mexican highlands, [4]. Botanically, maize (Zea mays L) belongs to the grass family grammeaneae (Poaceae). It is an annual plant with an extensive fibrous root system. And it is a diploid species with a chromosome number of $2 n=2 x=20$, [5].

\subsection{Months and Periods of Maturity of Maize (Zea Mays L) in Nigeria}

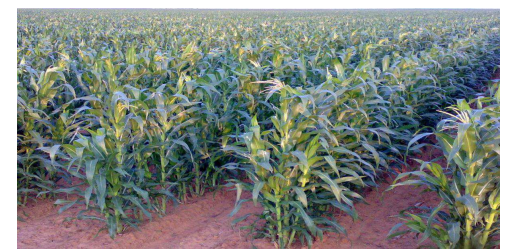

Figure 3. Maize (Zea Mays L), Months and Periods of Maturity.
Maize matures very fast. Between 3-4 months after planting, this crop will be ready for harvest. In the Southern Nigeria, early maize is sown by March/April, for early maturing seed variety and by July/August for late maturing seed variety; while in the Northern Nigeria, early maize is sown by May/June. Harvesting of early maize is done by May and Late Maize is harvested by October. After three or four months of tending the maize plant, the farmers is ready to harvest.

\subsection{Maize (Zea Mays L), Spoilage Before Harvest and Storage in Nigeria}

In order to maintain high quality of maize for both short term and long term harvest and storage, maize should be protected from weather (including relative humidity and temperature), growth of microorganisms and insects, [6]. Fungal growth in maize is facilitated by hot and humid conditions, [7]. Drought, humidity, temperature, insects, infestation, and rough handling have been suggested as factors which contributed to the presence of fungi and subsequently toxins in agricultural products, [8].

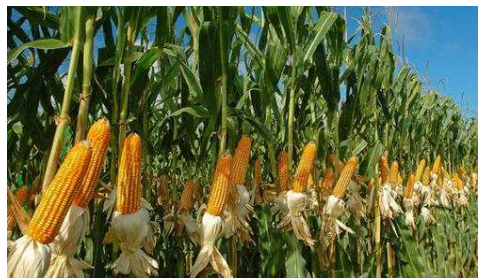

Figure 4. Maize (Zea mays L), Although, Commercially Lucrative, Some Risks are Connected in Growing It and Should be well Understood, because, Maize is Extremely Sensitive to Droughts, Insects and Pests.

Although, maize is commercially lucrative, there are some risks connected in growing it. This is because, maize is extremely sensitive to droughts, insects and pests. In Nigeria and other African countries, these may lead to crop's failure and can resulted to famine, in some cases. Insect pests can seriously reduce plant implantation, plant population, plant growth and subsequent yield potential, and must be monitored prior to planting. Seed treatments helps deter food. Watering in dry weather prevents the hulls from loosening. Diseases and insects in maize farming like (Downy, mildew and leaf spot), if the affected plants is not removed, and sprayed with (mancozeb, $1 \mathrm{~kg}$ per hectare of land), 20 days after sowing, usually causes the maize to dry and die. Black earwigs is a sporadic and potentially important pest of maize. Black earwigs eat newly sealed seed and the roots of crops resulting in a poor establishment. Birds are always problems to maize. They eat newly sealed seeds and destroy the entire root. Design a rough cloth on dry trees, like a stature of human being in all conspicuous areas inside the farm. (as wind blows, since they are birds, they ran away and never turn back). True wireworm larvae: causes damaged to the root or body of the seedlings. Then, crop growth will be delayed, by dying. False wireworm larvae: attacked the seed during the process of formation, including the shoots of young plants in the spring, resulting in uneven stands. Spray 
with (mancozeb, $1 \mathrm{~kg}$ per hectare of land), 20 days after sowing.

\subsection{Humid Condition Needed for Maize (Zea Mays L), Storage if Harvested}

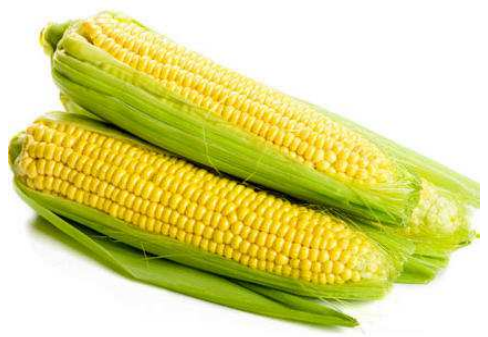

Figure 5. Maize (Zea mays L), If Harvested, Need be Stored Under Hot and Humid Conditions, Most Farmers Lack Proper Knowledge, and Equipment Methods of Drying Grains. Exposure to Moist and Humid Conditions During Storage Will Cause the Kennel to Absorb Water from the Surroundings, [9].

Maize, like other stored products is hygroscopic in nature and tends to absorb or release moisture. Even if properly dried, after harvest, exposure to moist and humid conditions during storage will cause the kennel to absorb water from the surroundings, leading to increase in maize moisture content, which resulted in enhanced deterioration, [10]. In tropical and sub tropical countries, a large proportion of the grain, (such as maize) is harvested and stored under hot and humid conditions, and most farmers lack proper knowledge, equipment methods of drying grains, [11]. Subsequently, the maize is stored while still relatively moist and warmth and high moisture contents can result in rapid deterioration of the grain and promote the growth of microorganisms (e.g. fungi and bacteria), and insects in the grains, [12]. The current estimates of the cost of grain loss due to insect and microorganisms, damage of grain stored in developing countries each year ranged from $\$ 500$ million to $\$ 1$ billion, [13]. Also reported that insects in grain enhanced mould development. because they increase moisture content and temperature, and open areas of the grain for attack. Fungal growth in maize is facilitated by hot and humid conditions, [14].

\section{Study Area}

The study has been conducted in Osun [pronounced; ' $O$ ' shoon]. Osun State is an inland State in South-Western Nigeria. Its capital is Osogbo. It has a population of 3.4 million and of $9,251 \mathrm{~km}^{2}$ in Area. It is bounded in the North by Ekiti State and partly by Ondo State, in the South by Ogun State and in the West by Oyo State. Osun is home to several of Nigeria's most famous landmarks, including the campus of Obafemi Awolowo University; Nigeria's preeminent institution of higher learning. The university also located in the ancient town of Ile - Ife, an important early centre of political and religious development for Yoruba culture. Other important cities and towns include the ancient Kingdom-capitals of Oke-Ila Orangun, Ila-Orangun, IjebuJesa, Ede, Iwo, Ejigbo, Modakeke, Ibokun, Ode-Omu, Ifetedo, Esa-Oke, Ilesa and Igbajo.

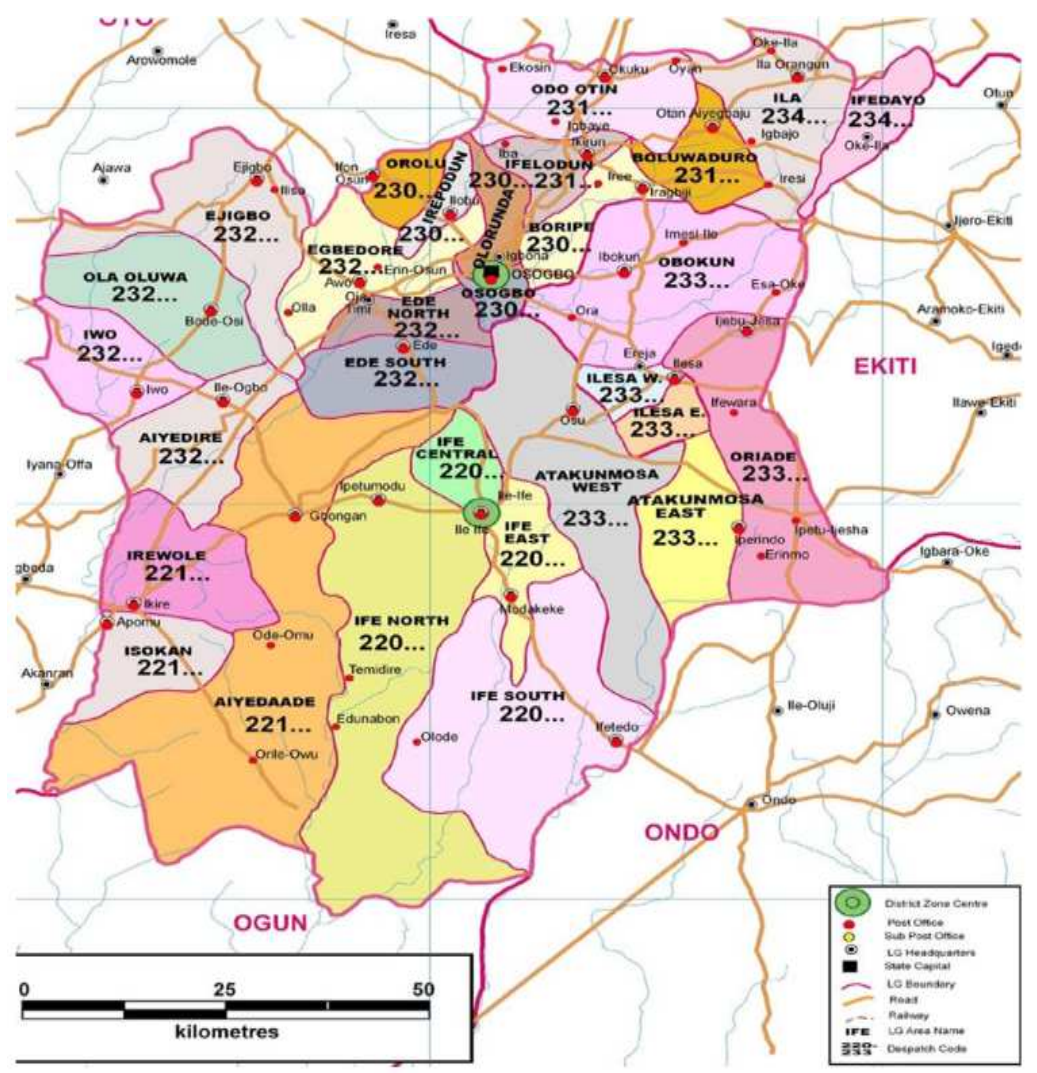

Figure 6. The Study Area Map of Osun State. 


\section{Material and Methods}

The responses of the farmers in different locations of the four local government areas can be seen from the decision table as below:

Table 1. The Decision Table.

\begin{tabular}{|c|c|c|c|}
\hline Sub & Above 70\% & Below 30\% & Open headed Questionnaires \\
\hline Computerized Analysis on spoilage of maize before harvest and storage is important & $\mathrm{X}$ & & \\
\hline I do not know & & $\mathrm{X}$ & \\
\hline State open questionnaires & & & $\mathrm{X}$ \\
\hline
\end{tabular}

The below are the points ticked by the majority of the people (above $70 \%$ table 1) from the questionnaires who understood and supported that, computerized analysis on spoilage of maize before harvest and storage in Osun State, Nigeria, was important:

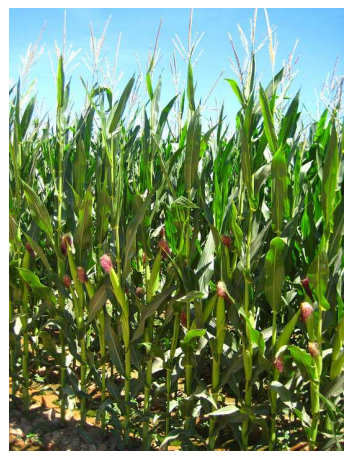

Figure 7. Maize (Zea mays L), Importance.

[a]. Maize may prevent diabetes and hypertension. [b]. Maize has anti-cancer properties. [c]. It is the most productive grain crops in the middle and northern belts of Nigeria where sunshine is adaptable and rainfall is moderate. [d]. The crop is richer in vitamins A,, and E, carbohydrates, essential minerals, and contain $9 \%$ protein. [e]. In all parts of Africa, green (fresh) maize is boiled or roasted in its cob and served as snacks. [f]. Maize helps in preventing skin problems. [g]. Maize is often consumed as vegetable. [h]. It serves as a basic raw materials to thousands of industrial products that may includes: alcoholic, beverages, pharmaceutical, food sweeteners, food cereals, cosmetic and films, gums, package, textile, paper industries and so on. [i]. Maize helps in improving vision. [j]. As one of African's dominant food crops, maize can be consumed in varied forms, such as: maize flour for confectionaries, semo (for swallow with soup), as corn beef, mill (for animals feeding), as roaster corn, it can be boiled or prepared as porridge. [k]. Maize is good for health digestion due to fibber content. [1]. Maize helps in lowering LDB (bad) cholesterol. [m]. In Nigeria, more than $60 \%$ of maize production is also consumed by industrial sector for the production of beer, malt drinks, maize flakes, starch, syrup, dextrose, and animal feed, because there is so much value in the industrial processing of maize, especially into animal feed. [n]. Maize is beneficial for the heart.. [o]. In tropical and sub tropical countries, a large proportion of the grain, (such as maize) is harvested and stored under hot and humid conditions, and most farmers lack proper knowledge, equipment methods of drying grains. [p]. Insect pests can seriously reduce plant implantation, plant population, plant growth and subsequent yield potential, and must be monitored prior to planting. [q]. Birds are always problems to maize. They eat newly sealed seeds and destroy the entire root. To control them, design a rough cloth on dry trees, like a stature of human being in all conspicuous areas inside the farm. (as wind blows, since they are birds, they ran away and never turn back). [r]. Black earwigs is a sporadic and potentially important pest of maize. Black earwigs eat newly sealed seed and the roots of crops resulting in a poor establishment. [s]. Maize is rich in dietary $\mathrm{D}$ and calories which are a good source of energy.

\section{Results and Discussion}

Questionnaires were distributed to 4 Local government areas that is, (Ife East, Ife South, Ife Central and Ife North). The results from the questionnaires however revealed that the importance of computerized analysis on spoilage of maize (Zea mays L), before harvest and storage in Osun State, Nigeria are manifold:

There was a significant difference on the people in all the local government areas visited, $(\mathrm{p}>0.05)$.

Table 2. People's respondent.

\begin{tabular}{|c|c|c|c|c|c|c|c|c|}
\hline Wards & Ife East & & Ife South & & Ife Central & & Ife North & \\
\hline \multirow[t]{2}{*}{$\begin{array}{l}\text { People's } \\
\text { Response }\end{array}$} & $\begin{array}{l}\text { The importance of } \\
\text { computerized analysis } \\
\text { on spoilage of maize } \\
\text { (Zea Mays L), before } \\
\text { harvest and storage in } \\
\text { Osun State. }\end{array}$ & $\begin{array}{l}\text { I do not } \\
\text { Know }\end{array}$ & $\begin{array}{l}\text { The importance of } \\
\text { computerized } \\
\text { analysis on spoilage } \\
\text { of maize (Zea Mays } \\
\text { L), before harvest } \\
\text { and storage in Osun } \\
\text { State. }\end{array}$ & $\begin{array}{l}\text { I do not } \\
\text { Know }\end{array}$ & $\begin{array}{l}\text { The importance of } \\
\text { computerized } \\
\text { analysis on } \\
\text { spoilage of maize } \\
\text { (Zea Mays L), } \\
\text { before harvest and } \\
\text { storage in Osun } \\
\text { State. }\end{array}$ & $\begin{array}{l}\text { I do not } \\
\text { Know }\end{array}$ & $\begin{array}{l}\text { The importance of } \\
\text { computerized } \\
\text { analysis on } \\
\text { spoilage of maize } \\
\text { (Zea Mays L), } \\
\text { before harvest and } \\
\text { storage in Osun } \\
\text { State. }\end{array}$ & $\begin{array}{l}\text { I do not } \\
\text { Know }\end{array}$ \\
\hline & $70170.1 \%$ & $\begin{array}{l}299 \\
29.9 \%\end{array}$ & $69769.7 \%$ & $\begin{array}{l}303 \\
30.3 \%\end{array}$ & $66566.5 \%$ & $\begin{array}{l}335 \\
33.5 \%\end{array}$ & $66866.8 \%$ & $\begin{array}{l}332 \\
33.2 \%\end{array}$ \\
\hline
\end{tabular}


From the above table 2, in Ife East, there are 701 people's response with $70.1 \%$, Ife South, 697 with $69.7 \%$, Ife Central, 655 with $65.5 \%$, and Ife North, 668 with $66.8 \%$, were those people who supported the importance of computerized analysis on spoilage of maize (Zea mays L), before harvest and storage in Osun State, while in Ife East, 299 with 29.9\%,
Ife South, 303 with $30.3 \%$, Ife Central, 335 with $33.5 \%$, and Ife North, 332 with $33.2 \%$ respectively, could not even know whether there was any needy for the importance of computerized analysis on spoilage of maize (Zea mays L), before harvest and storage in Osun State, or not.

Table 3. The summary data collected, from the 4 Local Governments sampled, out of which 900 were used in each local government.

\begin{tabular}{|c|c|c|c|c|c|c|c|c|c|}
\hline \multirow[t]{2}{*}{ LOCAL GOVERNMENT } & \multirow{2}{*}{$\begin{array}{l}\text { LOCATION } \\
\text { A }\end{array}$} & \multicolumn{2}{|c|}{ IFE EAST } & \multicolumn{2}{|c|}{ IFE SOUTH } & \multicolumn{2}{|c|}{ IFE CENTRAL } & \multicolumn{2}{|c|}{ IFE NORTH } \\
\hline & & 72 & 28 & 68 & 32 & 52 & 48 & 58 & 42 \\
\hline \multirow{8}{*}{ Peoples Respondent } & $\mathrm{B}$ & 70 & 30 & 62 & 38 & 59 & 41 & 69 & 31 \\
\hline & $\mathrm{C}$ & 62 & 38 & 74 & 26 & 58 & 42 & 65 & 35 \\
\hline & $\mathrm{D}$ & 64 & 36 & 65 & 35 & 68 & 32 & 66 & 34 \\
\hline & $\mathrm{E}$ & 76 & 24 & 66 & 34 & 74 & 26 & 62 & 38 \\
\hline & $\mathrm{F}$ & 75 & 25 & 68 & 32 & 76 & 24 & 74 & 26 \\
\hline & G & 63 & 37 & 78 & 22 & 78 & 22 & 76 & 24 \\
\hline & $\mathrm{I}$ & 74 & 26 & 74 & 26 & 65 & 35 & 64 & 36 \\
\hline & $\mathrm{J}$ & 78 & 22 & 70 & 30 & 73 & 27 & 71 & 29 \\
\hline TOTAL $=$ & 10 & 701 & 299 & 697 & 303 & 665 & 335 & 668 & 332 \\
\hline Grand Total $=$ & 10 & 1000 & & 1000 & & 1000 & & 1000 & \\
\hline
\end{tabular}

Table 4. Descriptive statistics.

\begin{tabular}{llll}
\hline Descriptive Statistics & & & \\
\hline & Mean & Std. Deviation & N \\
\hline IFEEAST & 70.1000 & 5.80134 & 10 \\
IFESOUTH & 69.7000 & 4.85455 & 10 \\
IFECENTRAL & 66.5000 & 8.72098 & 10 \\
IFENORTH & 66.8000 & 5.63323 & 10 \\
\hline
\end{tabular}

CORRELATIONS

/VARIABLES=IFEEAST IFESOUTH IFECENTRAL IFENORTH

/PRINT=TWOTAIL NOSIG

/STATISTICS DESCRIPTIVES

/MISSING=PAIRWISE.

Table 5. Pearson Correlation.

\begin{tabular}{|c|c|c|c|c|c|}
\hline \multicolumn{6}{|l|}{ Correlations } \\
\hline & & IFEEAST & IFESOUTH & IFECENTRAL & IFENORTH \\
\hline \multirow{3}{*}{ IFEEAST } & Pearson Correlation & 1 & -.338 & .223 & -.074 \\
\hline & Sig. (2-tailed) & & .339 & .536 & .839 \\
\hline & $\mathrm{N}$ & 10 & 10 & 10 & 10 \\
\hline \multirow{3}{*}{ IFESOUTH } & Pearson Correlation & -.338 & 1 & .198 & .229 \\
\hline & Sig. (2-tailed) & .339 & & .583 & .524 \\
\hline & $\mathrm{N}$ & 10 & 10 & 10 & 10 \\
\hline \multirow[t]{2}{*}{ IFECENTRAL } & Sig. (2-tailed) & .536 & .583 & & .023 \\
\hline & $\mathrm{N}$ & 10 & 10 & 10 & 10 \\
\hline \multirow{3}{*}{ IFENORTH } & Pearson Correlation & -.074 & .229 & $.706^{*}$ & 1 \\
\hline & Sig. (2-tailed) & .839 & .524 & .023 & \\
\hline & $\mathrm{N}$ & 10 & 10 & 10 & 10 \\
\hline
\end{tabular}

*. Correlation is significant at the 0.05 level (2-tailed).

FREQUENCIES VARIABLES=IFEEAST IFESOUTH IFECENTRAL IFENORTH

NTILES $=4$

/NTILES $=10$

/STATISTICS=STDDEV VARIANCE RANGE MINIMUM MAXIMUM SEMEAN MEAN MEDIAN MODE SUM SKEWNESS SESKEW

KURTOSIS SEKURT

/GROUPED=IFEEAST IFESOUTH IFECENTRAL IFENORTH

/PIECHART PERCENT 
/ORDER=ANALYSIS.

Frequencies

Table 6. The mode, median, mean, std. Deviation etc., of the 4 local governments.

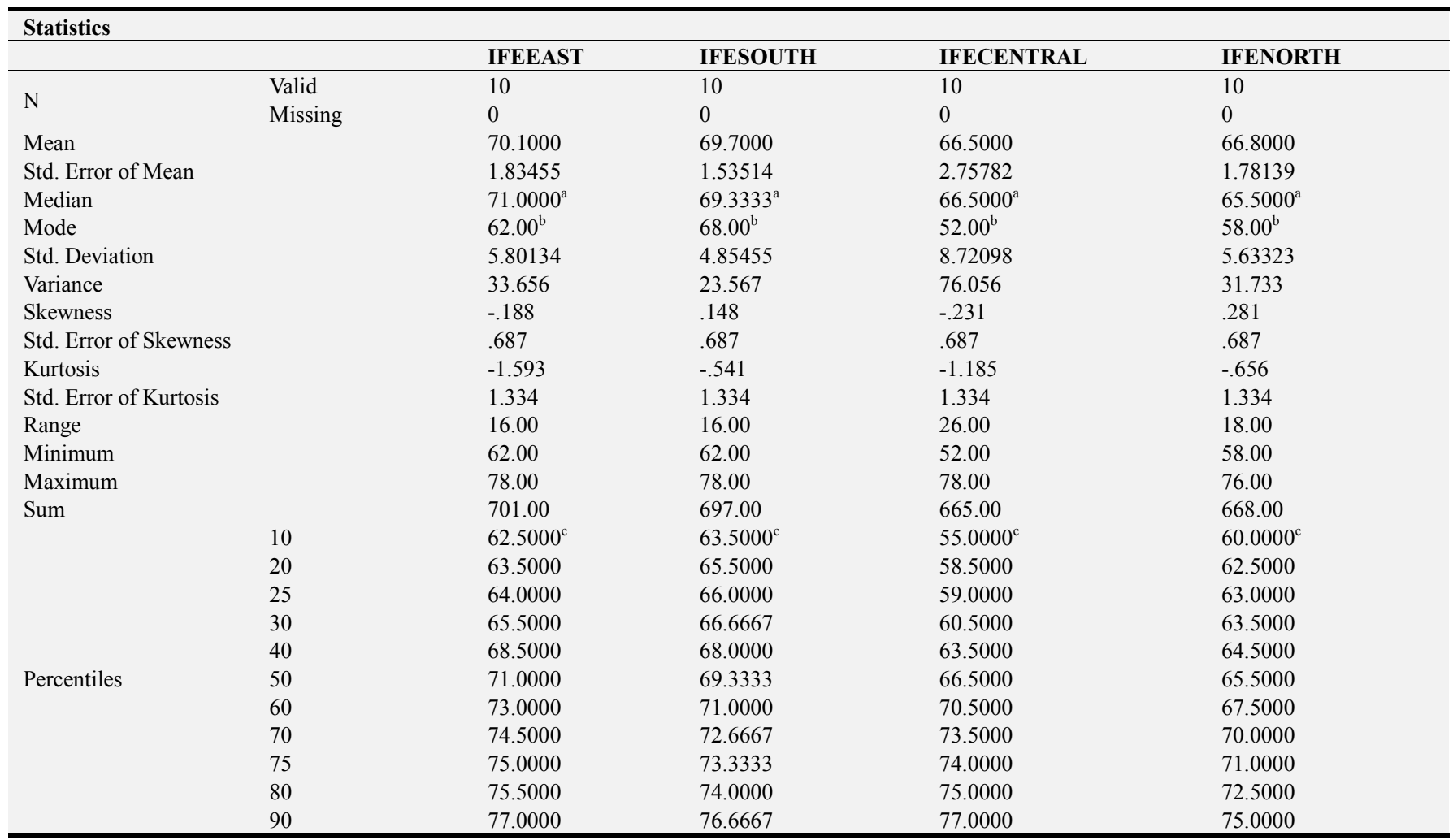

a. Calculated from grouped data.

b. Multiple modes exist. The smallest value is shown

c. Percentiles are calculated from grouped data.

Frequency Table

Tables $(7,8,9,10)$, the frequency Tables of all the 4 (four) Local Government Areas sampled.

Table 7. Valid and cumulative\% of Ife East.

\begin{tabular}{|c|c|c|c|c|c|}
\hline \multicolumn{6}{|c|}{ IFEEAST } \\
\hline & & Frequency & Percent & $\begin{array}{l}\text { Valid } \\
\text { Percent }\end{array}$ & $\begin{array}{l}\text { Cumulative } \\
\text { Percent }\end{array}$ \\
\hline \multirow{11}{*}{ Valid } & 62.00 & 1 & 10.0 & 10.0 & 10.0 \\
\hline & 63.00 & 1 & 10.0 & 10.0 & 20.0 \\
\hline & 64.00 & 1 & 10.0 & 10.0 & 30.0 \\
\hline & 67.00 & 1 & 10.0 & 10.0 & 40.0 \\
\hline & 70.00 & 1 & 10.0 & 10.0 & 50.0 \\
\hline & 72.00 & 1 & 10.0 & 10.0 & 60.0 \\
\hline & 74.00 & 1 & 10.0 & 10.0 & 70.0 \\
\hline & 75.00 & 1 & 10.0 & 10.0 & 80.0 \\
\hline & 76.00 & 1 & 10.0 & 10.0 & 90.0 \\
\hline & 78.00 & 1 & 10.0 & 10.0 & 100.0 \\
\hline & Total & 10 & 100.0 & 100.0 & \\
\hline
\end{tabular}

Table 8. Valid and cumulative\% of Ife South.

\begin{tabular}{|c|c|c|c|c|c|}
\hline \multicolumn{6}{|c|}{ Ife south } \\
\hline & & Frequency & Percent & $\begin{array}{l}\text { Valid } \\
\text { Percent }\end{array}$ & $\begin{array}{l}\text { Cumulative } \\
\text { Percent }\end{array}$ \\
\hline \multirow{3}{*}{ Valid } & 62.00 & 1 & 10.0 & 10.0 & 10.0 \\
\hline & 63.00 & 1 & 10.0 & 10.0 & 20.0 \\
\hline & 64.00 & 1 & 10.0 & 10.0 & 30.0 \\
\hline
\end{tabular}

\begin{tabular}{cllll}
\hline Ife south & & & & \\
\hline & Frequency & Percent & $\begin{array}{l}\text { Valid } \\
\text { Percent }\end{array}$ & $\begin{array}{l}\text { Cumulative } \\
\text { Percent }\end{array}$ \\
\hline 67.00 & 1 & 10.0 & 10.0 & 40.0 \\
70.00 & 1 & 10.0 & 10.0 & 50.0 \\
72.00 & 1 & 10.0 & 10.0 & 60.0 \\
74.00 & 1 & 10.0 & 10.0 & 70.0 \\
75.00 & 1 & 10.0 & 10.0 & 80.0 \\
76.00 & 1 & 10.0 & 10.0 & 90.0 \\
78.00 & 1 & 10.0 & 10.0 & 100.0 \\
Total & 10 & 100.0 & 100.0 & \\
\hline
\end{tabular}

Table 9. Valid and cumulative\% of Ife Central.

\begin{tabular}{ccccll}
\hline IFECENTRAL & & & & \\
\hline \multirow{6}{*}{ Frequency } & Percent & $\begin{array}{l}\text { Valid } \\
\text { Percent }\end{array}$ & $\begin{array}{l}\text { Cumulative } \\
\text { Percent }\end{array}$ \\
\hline \multirow{6}{*}{ Valid } & 52.00 & 1 & 10.0 & 10.0 & 10.0 \\
& 58.00 & 1 & 10.0 & 10.0 & 20.0 \\
& 59.00 & 1 & 10.0 & 10.0 & 30.0 \\
& 62.00 & 1 & 10.0 & 10.0 & 40.0 \\
& 65.00 & 1 & 10.0 & 10.0 & 50.0 \\
& 68.00 & 1 & 10.0 & 10.0 & 60.0 \\
& 73.00 & 1 & 10.0 & 10.0 & 70.0 \\
& 74.00 & 1 & 10.0 & 10.0 & 80.0 \\
& 76.00 & 1 & 10.0 & 10.0 & 90.0 \\
& 78.00 & 1 & 10.0 & 10.0 & 100.0 \\
& Total & 10 & 100.0 & 100.0 & \\
\hline
\end{tabular}


Table 10. Valid and cumulative\% of Ife North.

\begin{tabular}{clllll}
\hline IFENORTH & & & & \\
\hline & Frequency & Percent & $\begin{array}{l}\text { Valid } \\
\text { Percent }\end{array}$ & $\begin{array}{l}\text { Cumulative } \\
\text { Percent }\end{array}$ \\
\hline 58.00 & 1 & 10.0 & 10.0 & 10.0 \\
62.00 & 1 & 10.0 & 10.0 & 20.0 \\
63.00 & 1 & 10.0 & 10.0 & 30.0 \\
64.00 & 1 & 10.0 & 10.0 & 40.0 \\
& 65.00 & 1 & 10.0 & 10.0 & 50.0 \\
Valid & 66.00 & 1 & 10.0 & 10.0 & 60.0 \\
& 69.00 & 1 & 10.0 & 10.0 & 70.0 \\
& 71.00 & 1 & 10.0 & 10.0 & 80.0 \\
74.00 & 1 & 10.0 & 10.0 & 90.0 \\
76.00 & 1 & 10.0 & 10.0 & 100.0 \\
Total & 10 & 100.0 & 100.0 & \\
\hline
\end{tabular}

Figures $(8,9,10$ and 11) showing the Pie Chart, of all the (4) four Local Government sampled.

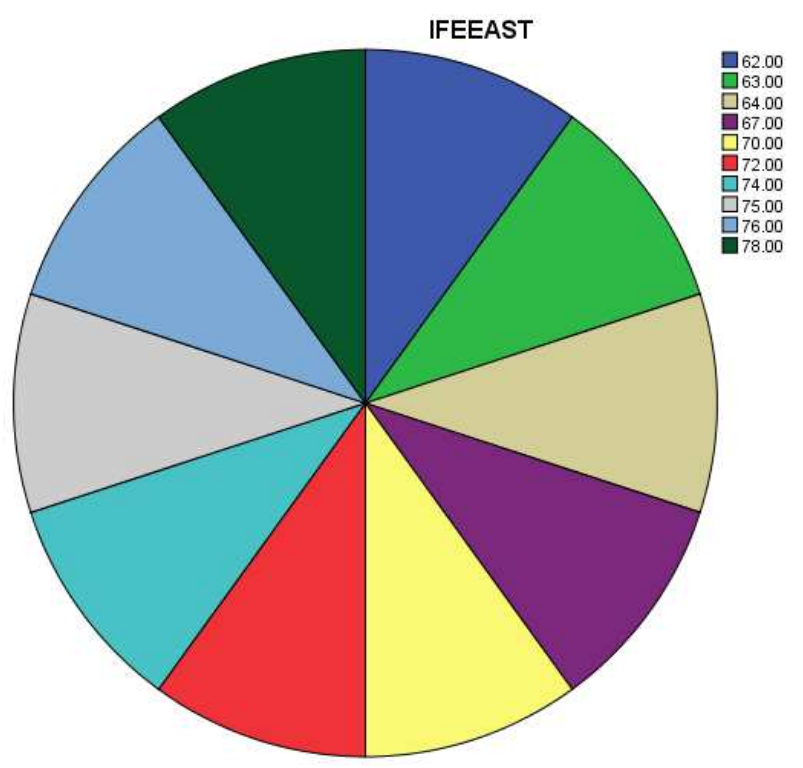

Figure 8. Pie chart of Ife East.

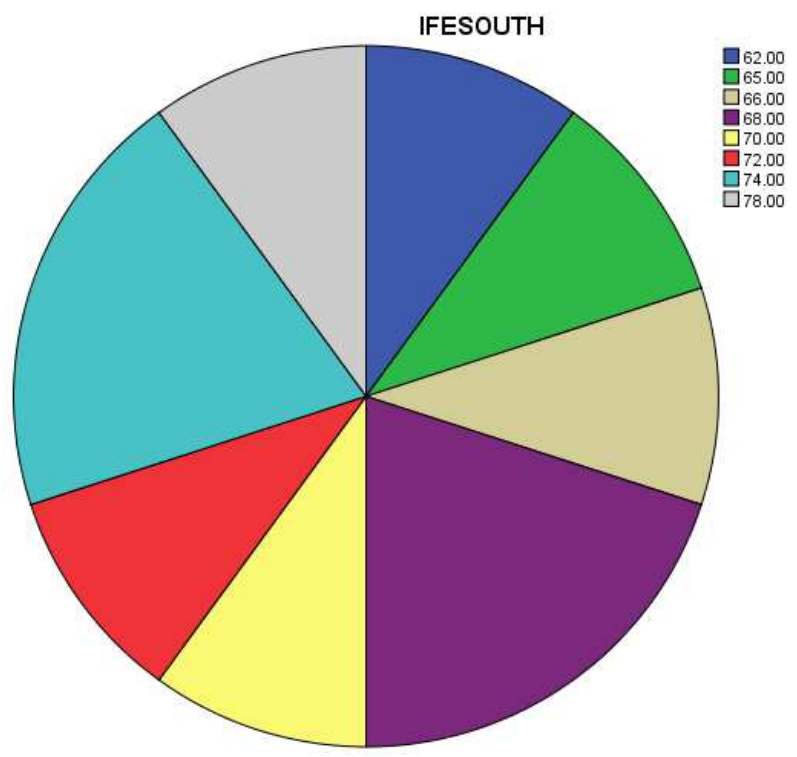

Figure 9. Pie chart of Ife South.

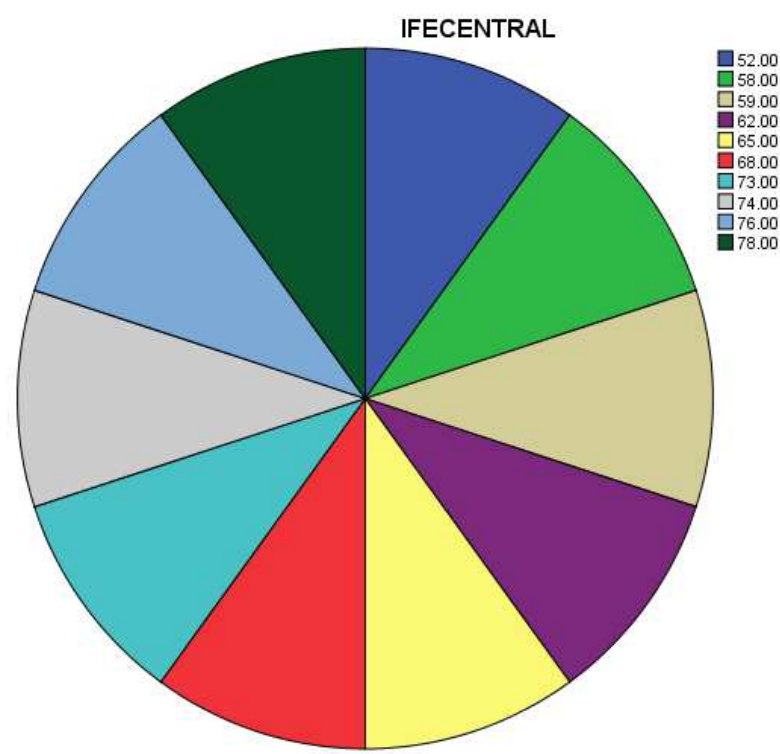

Figure 10. Pie chart of Ife Central.

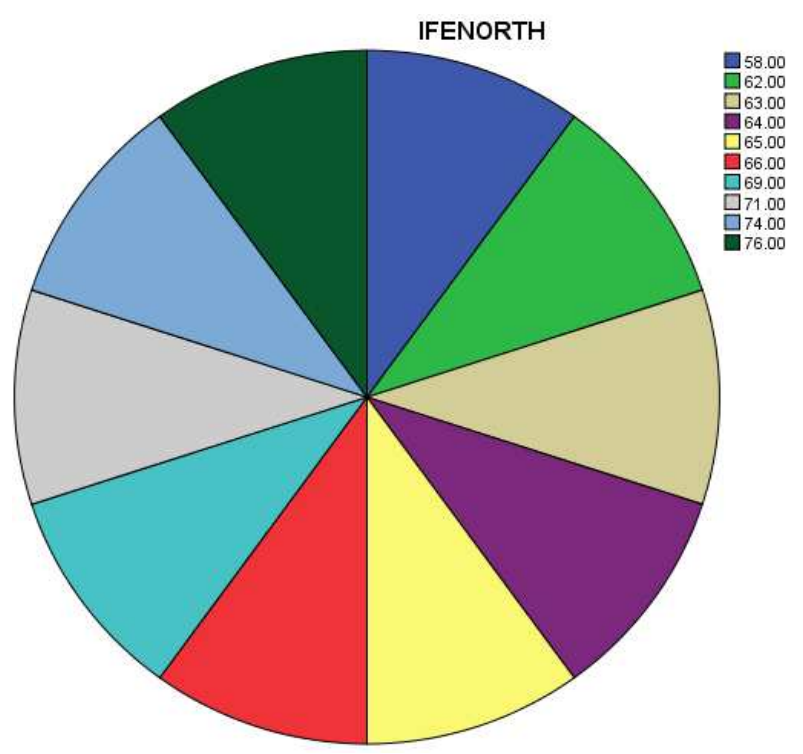

Figure 11. Pie chart of Ife North.

\section{Recommendations}

1. Workshop at different intervals should be organised in Ile-Ife Kingdom, and Osun State, in general, to farmers, so as to educate them in the uses of current farmer's equipments, to increase their maize output production and eradicate maize spoilage. 2. Some of the rural areas roads in Osun State, Nigeria, are bad. Government should provide good roads to farmers, to enable ease carriage of their maize harvest crops, to save the cost of transportation of carriage of food crops to urban areas. 3. Government should provide electricity to rural areas for farmers, to enable them to stay longer in their farms, for maximum increase in their maize harvest Production. 4. Nigerian Government should encourage Agriculture, and Maize plantation, both at the secondary level to higher Institution's level, since food is health, and health is wealth. 5. Government should erect large storage at intervals for farmers 
in order to encourage them to keep their agricultural products, so as to minimize frequent maize spoilage. 6 . Adult computer awareness training should be made possible and effective to all farmers, in all the local governments, in both the rural and urban areas of Nigeria, to make them become computer literate, and as in the era of computing, maize spoilage will definitely be reduced. 7. Government should encourage farmers by providing and bringing agricultural equipments like cutlasses, sprayers, hoes, etc., and farm products like herbicides, fertilizers, insecticides, etc., closer to them, so as to reduce the cost of maize harvest to the buyers.

\section{Conclusion}

The following conclusions are made based on the findings of this study. Since maize as a crop, is not only richer in vitamins $\mathrm{A}$, and $\mathrm{E}$, carbohydrates, essential minerals, and contain $9 \%$ protein, it is also rich in dietary $\mathrm{D}$ and calories which are a good source of energy for human being. And as one of African's dominant food crops, that can be consumed in varied forms, such as: maize flour for confectionaries, semo (for swallow with soup), as corn beef, mill (for animals feeding), as roaster corn, to be boiled or prepared as porridge; in Nigeria, more than $60 \%$ of maize production is also consumed by industrial sector for the production of beer, malt drinks, maize flakes, starch, syrup, dextrose, and animal feed, because there is so much value in the industrial processing of maize, especially into animal feed; the results of this study provide the empirical evidence that the importance of computerized analysis on spoilage of maize before harvest and storage, in Osun State, Nigeria, has enhanced the farmers and people's achievement in Osun State in general and Nigeria at large. The farmers and the people of Osun State, therefore should use the computerized analysis on spoilage of maize before harvest and storage, in Osun State, Nigeria, to argument their agricultural knowledge, business techniques, and decision aids, in order to attain minimum goal needed for everybody in the society.

\section{Acknowledgements}

The Author wishes to express his appreciations to all especially those whose papers that are shown in my references to provide the premise for this study, and Dr. / Chief RamondA dedoyin, (The ATOBATELE of The "SOURCE" AND MAYE of The Yoruba Kingdom), The Chancellor and Founder of Oduduwa University for providing the fund and space to carry out this research work / study.

\section{References}

[1] Aderinlewo E. O., 1982. Basic Secondary Science Book 1. Published by Evans Brothers Limited. Montague House, Russell square London WC1B5BX. Composition in 11 on 13 point century by Film type services Limited, Scarborough, North Yorkshire and Printed by William Clowes (Beccles) Limited, Beccles and London ISBN 0237505274. NPR 1137.
[2] AshutoshKar, 2011. Advanced Practical Chemistry. First Edition. Printed in India at Saras Graphics, Rai, Haryana. Typeset at Goswami Associates, Delhi. Publishing for one world. New Age International (P) Limited, Publishers. 4835/24, Ansari Road, Daryaganj, New Delhi-110002. ISBN (0): $81-224-1539$ - 9. ISBN (13): $978-81-224-1539$ 1.

[3] C. M. A. Ademoroti, 2016. Environmental Chemistry \& Toxicology. Printed and Printed by: Folex Press Ltd., Ibadan. Typing and Manuscript: Mareh Prints and Consultancy. 47, Jona Akpaborie Street, BDPA, Ugbowo Estate, Benin. ISBN: 978-32413-1-1.

[4] Dr. Tilak Ram, 2013. Food Chemistry. Published in India by Random Publications. 4376- A/4B. Gall Murari Lai, Ansari Road, New Delhi - 110002. Typesetting by: Friends Media, Delhi - 110087. Digitally Printed at: Replica Press Pvt. Ltd. ISBN $978-93-5111-032-3$.

[5] Elservier, E. 2009. Guide to Protein Purification. $2^{\text {nd }}$ Edition. Academic Press. 525B street, suite 1900. San Diego, a 92101 - 4495, USA, 30 corporate Drive. Suite 400, Burlington, MA 01803, USA. 32 Jamestown Road, London. NW1 7BY, UK. ISBN: $978-0-12-374536-1$ (hardback). ISBN: $978-0-$ $12-374978-9$ (paper back). ISSN: $0076-6879$.

[6] Erelu, O. O., 2008. Cocoa for Health and Wealth. A Paper presented in a Fourth Cocoa Day Celebration in Osun State between $22^{\text {nd }}-24^{\text {th }}$ April.

[7] Fan Y. Ding Z. Yang L. et al. A Preliminary Study on Bioactivity of Orange and Tangerine Peal extracts against Apulia and mites. ZhongguoZhong Yao ZaZhi 1995 Jul: 20 (7): 397-8, 446. 1995. PMID: 13090.

[8] George Coulouris, Jean Dollimore and Tim Kindberg, 2011. Distributed Systems, Concepts and Design, $4^{\text {th }}$ Edition. Published by Dorling Kindersley [India] Pvt. Ltd. Licensees of Pearson Education in South Asia. HeadOffice: $7^{\text {th }}$ floor, Knowledge Bouleward. A-8 [A], Sector-62. Noida-201309, U. P. India Registered Office: 11Community Centre, Panchsheel Park. New Delhi110017, India. Printed in India by Municipal Press Ltd. ISBN 97881-317-1840-7. Authorized adaptation from the United Kingdom Edition, Entitled Distributed System Concepts and Design. Forth Edition, ISBN: 9780321263544 by Koulouris, George: Doll more, Jean; Kind berg, Tim; Published by Education, Ltd. Copyright @ 2005. Indian Subcontinent Adaptation copyright@2009 Dorling Kindersley [India] Pvt. Ltd.

[9] Gordon M. Wardlaw, 2003. Contemporary Nutrition Issues and Insight. Fifth Edition. Published by McGraw - hill, a business unit of McGraw - Hill Companies, Inc., 1221 avenue of the Americas, New York, NY 10020. ISBN: $0-07-$ $286530-X$. ISBN: $0-07-119903-\mathrm{X}(15 \mathrm{E})$. International Edition. ISBN: $0-07-118808-\mathrm{X}$.

[10] Honow R., Laube N. Schneider A, Kessier T. Hesser. Influence of grape fruit, Orange, and apple juice consumption on urinary variables and risk of crystallization. Br. Intr. Aug: 90 (2) 295-300.2003. PMID: 12908889.

[11] Jill Norman, 1997. The Classic Herb Cook Book. First published in Great Britain by Dorling Kindersley Limited. 9, Henrietta Street, London WC2E8PS. Reprint in 1997. A CIP for this book is available from the British Library. ISBN: 0751303232. Reproduced in Italy by Scanner Service SRL. Printed and bound in Italy by a Monadori, Veronica. 
[12] John R. Holum, 1975. Experiments in General Organic and Biological Chemistry. A laboratory Manual, Forth Edition. New York. London. Sydney. Toronto. Printed in the United State of America. 10987654321.

[13] Kumar R., 1984. Insect Pest Control. First Published in Great Britain. Printed and bound in Great Britain by Athenaeum Press Ltd. Gates head British Library Cataloguing in Publication Data. ISBN 0713180838. Member of the Holder Headline Group. 338 Euston Road, London WW1 3BH.

[14] Melvin Calvin and J. A Bass ham 1962. The Photosynthesis of Carbon Compounds. Library of Congress Catalogue Card Number: 62 - 10567. Manufactured in the United States of America. The Manuscripts was received November 15, 1961, and Published February 27, 1962. W. A. Benjamin, Inc. 2465 Broadway, New York 25, New York.

[15] Nyle C. Brandy, 1990. The nature and Properties of Soils. Printed in the United State of America by Mac Millian Publishing Company. Simon \& Schuster A. Viacon Company, Upper Saddle River, New Jersey, 074p58. ISBN 0-13-852444-0.

[16] Oduduwa University, 2016. General Inorganic Chemistry. Press Publication Ltd. 213, Egbeda / Idimu Road, Egbeda, Lagos. ISBN: 978-978-50449-5-9.

[17] Oluyole K. A., 2005. Evaluation of the Economic of Post Harvest Processing of Cocoa in Cross River State, Nigeria. Journal of Agriculture, Forestry and the Social Sciences.
[18] O. P. Agarwal, 2014. Organic Chemistry, Natural Products Volume - 1. Published by: Satyendra Rostogi, "mitra" for KRISHNA Prakasha media (P) Ltd. 11, Shivaji Road, Meerut - 25001 (U. P.) India. Printed at Majmoon Press, Meerut. Typing: DEBUG CC. (The computer concern) Ghaziabad, ISBN: $978-81-8283-556-6$.

[19] Rai H., 2004. Basic Industrial Biochemistry. Printed in India at Ram Pictograph, Delhi. Typeset at In-house. Publishing for one world. New Age International (P) limited. Publishers. 4835/24, An sari Road, Daryaganj, New Delhi-110002. ISBN: $978-81-224-3404-0.295$. C - $12-04-6261$.

[20] Rama Rao Nadendla, 2016. Principles of Organic Medicinal Chemistry. Published by New Age International (P) Ltd., Publishers. ISBN: 81-224-1571-7. Printed in India at Ajit Printers, Delhi. Typeset at Goswani Printers, Delhi.

[21] Rapisarda P. Tomaino A. Lo Cascio R., et al. Antioxidant effectiveness as influenced by Phenol content of fresh orange juices. J, Agric Food Chem. 1999 Nov: 47 (11): 4718-23-. 1999. PMID: 13080.

[22] S. K. Jain, 2001. Mineral Processing. For CBS Publishers and Distributors Pvt. Ltd. CBS Plaza, 4819/XI Prahlad Street, 24 An sari Road, Daryaganj, New Delhi - 110002, India. Ph: 23289259, 232668861, 23266867. ISBN: $81-239-0753-2$.

[23] TilakWasan, 2015. Solid Waste Pollution and Health Published at Arisari Road, 4383/4B, DargaGanj. New Delhi110002 (India). ISBN: $978-93-5056-306-9$. Discovery Publishing House PVT. Ltd. Printed at: Infinity Imaging Systems Delhi. 